Plant Production Science

http:/www.journals.zu.edu.eg/journalDisplay.aspx?Journalld=1\&queryType=Master

\title{
COMBINING ABILITY FOR EARLINESS, GRAIN YIELD AND ITS COMPONENTS IN SOME BREAD WHEAT GENOTYPES UNDER THE NORMAL AND LATE SOWING DATES
}

\author{
Hussien M.A. Shaban", S.A. Ghanim ${ }^{1}$, Naglaa Qabil ${ }^{1}$ and R.M.A. Koumber ${ }^{2}$ \\ 1. Agron. Dept., Fac. Agric., Zagazig Univ., Egypt \\ 2. Wheat Res. Dept., Field Crops Res. Inst., ARC, Giza, Egypt
}

Received: 29/04/2018 ; Accepted: 02/07/2018

\begin{abstract}
The present investigation was conducted at the Agricultural Research Station, ElGemmeiza, Egypt, during the two winter seasons of 2014/2015 and 2015/2016. A half diallel cross analysis was made among eight parental bread wheat cultivars to study mean squares, mean performance and combining ability for days to heading, days to maturity, number of spikes/plant, number of grains/ spike, 1000-grain weight, grain yield/plant and protein content. The parents and $F_{1}$ crosses were grown in a randomized complete block design with three replicates and were sown under two sowing dates i.e., $20^{\text {th }}$ November (normal sowing date) and $20^{\text {th }}$ December (late sowing date). Mean square due to parents, $F_{1}$ crosses as well as general combining ability (GCA) and specific combining ability (SCA) were highly significant for all studied characters under both sowing dates. The ratio of GCA/SCA variance was more than unity for each of days to heading, days to maturity, number of spikes/plant, number of grains/spike and protein content under the both sowing dates as well as 1000-grain weight under the late sowing one. Otherwise, it was less than unity for 1000-grain weight under the normal sowing date. Moreover, GCA/SCA ratio was near to unity for grain yield/plant under the two sowing dates. The parental wheat cultivar Gemmeiza 12 and $F_{1}$ crosses (Gemmeiza $7 \times$ Gemmeiza 11), (Gemmeiza 7× Gemmeiza 12), (Gemmeiza $7 \times$ Sids 12), $($ Gemmeiza $7 \times$ Misr 1), $($ Gemmeiza $9 \times$ Gemmeiza 11), (Gemmeiza $11 \times$ Giza 168), (Gemmeiza $11 \times$ Giza 171), (Gemmeiza $12 \times$ Sids 12) and (Misr $1 \times$ Giza 171) exhibited the lowest reduction percentage and HSI values in wheat grain yield. Therefore, these genotypes were more tolerant to heat stress as created by late sowing date. Whereas, the local parental cultivars Gemmeiza 7 and Misr 1 as well as the $F_{1}$ crosses (Gemmeiza $7 \times$ Gemmeiza 9), (Gemmeiza $9 \times$ Gemmeiza 12), (Gemmeiza $9 \times$ Misr 1), (Gemmeiza $9 \times$ Giza 168), (Gemmeiza $9 \times$ Giza 171), (Gemmeiza $11 \times$ Gemmeiza 12), $($ Gemmeiza $12 \times$ Misr 1), $($ Sids $12 \times$ Giza 171) and (Giza $168 \times$ Giza 171) offered the highest reduction percentage and HSI values. So, these genotypes were more sensitive to late sowing date (heat stress). The cultivars Gemmeiza 7, Gemmeiza 11 and sides 12 were the best general combiners for earliness characters. Meanwhile, the cultivar Giza 171 was the best combiner for grain yield and its components. Fourteen crosses exhibited highly significant and positive SCA effects for grain yield/plant under both sowing dates and were obtained from the three possible combinations between their respective parents of high $\times$ high, high $\times$ low and low $\times$ low GCA effects.
\end{abstract}

Key words: Diallel, bread wheat, mean squares, combining ability, heat stress.

\section{INTRODUCTION}

Wheat is one of the most strategic crops that should be grown in large areas for food security aspect. Egypt's total wheat production of grains

\footnotetext{
* Corresponding author: Tel. : +201064276448

E-mail address: shaban hes31@gmail.com
}

reached about 9 million tons produced from 3.25 million faddan (FAO, 2018). Increasing wheat production of Egypt is an essential requirement at the national level to meet the increasing wheat consumption. The total wheat production could 
be increased by developing high yield cultivars tolerant to environmental stresses (heat stress) and simultaneously applying proper cultural practices to ensure high production per unit area at different environments.

The performance of bread wheat genotypes with respect to earliness, yield and its components was studied by many authors. Khan (2016) and Kumar et al. (2017) evaluated the yield performance and its components of bread wheat genotypes, they found that genotypes were significantly differed.

Combining ability analysis proposed by Griffing (1956) provides useful information for selection of parents in terms of the behavior of their hybrids and is an indicator of nature of gene action. Different investigators have studied combining ability in bread wheat genotypes (Rizkalla et al., 2012; Abd-Allah, 2013; Abdallah et al., 2015; Qabil, 2017). High general combining ability indicated that additive gene effect was predominant. While, high specific combining ability effects are due to non-additive type of gene action.

The objectives of this study were to determine the mean squares of wheat genotypes, mean performance and combining ability for earliness, yield, its components and protein content under the impact of normal and late sowing dates.

\section{MATERIALS AND METHODS}

This investigation was carried out at the Experimental Farm, Gemmeiza Agriculture Research Station, Egypt during the two winter growing seasons of 2014/2015 and 2015/2016. Eight parental wheat genotypes were involved in a half diallel cross fashion, excluding reciprocals. The studied parental materials were chosen on the basis of wide differences among them in respect to the studied characters. The pedigree and origin of the wheat parental genotypes are presented in Table 1.

In the first season of 2014/2015, the eight parents were crossed to produce a half diallel set of crosses excluding reciprocal to obtain $28 \mathrm{~F}_{1}$ cross seeds. Therefore, in the second season $(2015 / 2016)$, the parents and their $F_{1}$ crosses were grown in a randomized complete block design with three replications and were sown on two sowing dates i.e., normal ( $20^{\text {th }}$ Nov.) and late $\left(20^{\text {th }}\right.$ Dec.) sowing dates. The experimental plot consisted of 3 rows for each parent and one row for each $F_{1}$ crosses. The row length was $2 \mathrm{~m}$, row to row and plant to plant spaces were 20 and $10 \mathrm{~cm}$, respectively. Ten guarded plants were chosen randomly of each parental cultivars and $F_{1}$ crosses and labeled to collect data on the following characters viz., days to heading (day), days to maturity (day), number of spikes /plant, number of grains/spike, 1000-grain weight (g.), grain yield/plant (g) and protein content (\%).

Data were subjected to analysis of variance technique (Steel et al., 1997), to establish the significant differences among parental genotypes and $\mathrm{F}_{1}$ crosses for various characters.

The reduction percentage of means due to late sowing for grain yield/plant was calculated as [(mean value of normal sowing genotype mean value of late sowing genotype) / mean value of normal sowing genotype] $\times 100$.

Heat sensitivity index (HSI) was used as a measure of heat tolerance in terms of minimization of the reduction in yield caused by unfavorable versus favorable environments. HSI was calculated for each genotype according to the formulae of Fisher and Maurer (1978):

$$
\mathrm{HSI}=(1-\mathrm{Y} s / \mathrm{Yp}) /(1-\overline{\mathrm{Y}} \mathrm{s} / \overline{\mathrm{Y}} \mathrm{p})
$$

Ys, $Y p, \bar{Y} s$ and $\bar{Y} p$ represent grain yield for each genotype under stress conditions, grain yield for each genotype under normal condition, mean of grain yield in all genotypes in late (stress) and normal conditions, respectively.

Analysis of combining ability was done according to the procedures given by Griffing (1956), using method 2, model 1 for the studied characters. The parameters of both general (GCA) and specific (SCA) combining abilities for the studied characters are estimated as follows:

$$
\begin{aligned}
& \text { SS due to }(\mathrm{GCA})=\frac{1}{\mathrm{P}+2}\left[\sum(\mathrm{x} i+\mathrm{x} i i)^{2}-\frac{4}{\mathrm{p}} \mathrm{x}^{2}\right] \\
& \text { SS due to }(\mathrm{SCA})=\sum \mathrm{i} \leq \sum \mathrm{jx} \mathrm{x}_{i j}-\frac{1}{\mathrm{p}+2} \sum \mathrm{i}(\mathrm{X} i+\mathrm{X} i i)^{2}+\frac{2}{(\mathrm{P}+1)(\mathrm{P}+2)} \mathrm{X}^{2}
\end{aligned}
$$

The general (gi) and specific (Sij) combining ability effects are estimated as follows: 
Table 1. Pedigree and origin of the parental bread wheat genotypes

\begin{tabular}{|c|c|c|c|}
\hline \multicolumn{2}{|c|}{ No. Genotype } & \multirow{2}{*}{$\begin{array}{l}\text { Pedigree } \\
\text { CMH } 74 \text { A. 630/SX// Seri 82/3/Agent }\end{array}$} & \multirow{2}{*}{$\frac{\text { Origin }}{\text { Egypt }}$} \\
\hline 1 & Gemmeiza 7 & & \\
\hline 2 & Gemmeiza 9 & ALD "S" HUAC "S" // CMH74A.630/5X CGM4583-5GM-1GM 0GM & Egypt \\
\hline 3 & Gemmeiza 11 & $\begin{array}{l}\text { BOW "S" /KVZ "S" //7C/Seri -82/3/Giza168/Sakha } 61 \text { GM 7892-2GM-1GM - } \\
\text { 2GM-1GM- 0GM }\end{array}$ & Egypt \\
\hline 4 & Gemmeiza 12 & $\begin{array}{l}\text { OTUS /3/SARA/THB//VEE CM//SS97Y002257-5Y-010M-010Y-010M-2Y-1M- } \\
\text { 0Y-0GM. }\end{array}$ & Egypt \\
\hline 5 & Sids12 & $\begin{array}{l}\text { BUC//7C/ALD/5/MAYA74/ON//1160147/3/BB/GLL/4/CHAT"S"/S/MAYA- } \\
\text { VUL//CMH74A.630/4*SX.SD7096-4SD-1SD-1SD-OSD }\end{array}$ & Egypt \\
\hline 6 & Misr 1 & $\begin{array}{l}\text { OASIS/KAUZ//4*PASTOR.CM//SS 00Y01881T-050M-030Y-030M-030WGY- } \\
\text { 33M-0Y-0S }\end{array}$ & Egypt \\
\hline 7 & Giza168 & MIL/BUC//Seri:CM93046-8M-OY-OM-2Y-OB. & Egypt \\
\hline 8 & Giza171 & Sakha 93/ Gemmeiza9 GZ2003-101-1GZ4Gz-1GZ-2GZ-OGZ. & Egypt \\
\hline
\end{tabular}

$$
\begin{gathered}
\hat{g} i=\frac{1}{\mathrm{P}+2}\left[\mathrm{X} i+\mathrm{X} i i-\frac{2}{\mathrm{p}} \mathrm{X}\right] \\
\mathrm{Si} \mathrm{j}=\mathrm{Xii}-\frac{1}{\mathrm{P}+2}[\mathrm{X} \mathbf{i}+\mathrm{Xii}+\mathrm{Xj}+\mathrm{Xjj}]+\frac{2}{(\mathrm{P}+1)(\mathrm{P}+2)} \mathrm{X}
\end{gathered}
$$

Standard error for effects and differences between effects were calculated as follows:

$$
\begin{gathered}
S E(g \hat{i})=\left[\frac{p-1}{p(p+2)} \delta^{2} e\right]^{\frac{1}{2}} \\
S E(S \hat{i} j)=\left[\frac{p^{2}+p+2}{(p+1)(p+2)} \delta^{2} e\right]^{\frac{1}{2}}
\end{gathered}
$$

Where:

$\mathrm{P}$ : Is the number of parents.

$\mathrm{X}_{\mathrm{i}}$ : Is the sum of the means of parent (i) and its crosses.

$\mathrm{X}_{\mathrm{ii}}$ : Is the mean of the parent (i).

$\mathrm{X} . .:$ Is the sum of the means of all genotypes.

$\mathrm{X}_{. \mathrm{j}}$ : Is the sum of means of parent (j) and its crosses.

$\mathrm{X}_{\mathrm{jj}}$ : Is the mean of the parent $(\mathrm{j})$.

$\sigma^{2} \mathrm{e}$ : Is the error mean square for the randomized complete block design.

\section{RESULTS AND DISCUSSION}

\section{Mean Squares}

Mean squares of earliness characters, yield, its components and protein content for parental wheat genotypes and their $F_{1}$ crosses under the normal and the late sowing dates are given in Table 2. The results indicated that there were highly significant differences among parental wheat genotypes and their $F_{1}$ crosses for the studied characters under both sowing dates. Thus, the results provide evidence for the presence of adequate amount of genetic variability valid for further biometrical assessments. In this respect, significant differences were detected among wheat parents and $F_{1}$ crosses for earliness and yield characters by many investigators (Gashaw et al., 2007; Anwar et al., 2009; ElMoselhy, 2009; Sedek, 2009; Rizkalla et al., 2012; Abdallah et al., 2015; Kumar et al., 2015; Ahmad et al., 2016; Hassan et al., 2016; Khan, 2016; Afridi et al., 2017; Kumar et al., 2017; Qabil, 2017).

Variance due to GCA and SCA (Table 2), indicated that GCA and SCA mean squares were highly significant for all studied characters under the normal and the late sowing dates, suggesting the importance of both additive and non-additive gene effects in the inheritance of all characters. The obtained results are in agreement with those reported by Ismail $\boldsymbol{e t}$ al. 
Table 2. Mean squares of eight parents and $F_{1}$ progenies of bread wheat for earliness characters, yield, its components and grain protein content (\%) under the two sowing dates

\begin{tabular}{|c|c|c|c|c|c|c|c|c|c|c|c|c|c|c|c|}
\hline \multirow[t]{2}{*}{ Source of variation } & \multirow[t]{2}{*}{ df } & \multicolumn{2}{|c|}{$\begin{array}{c}\text { Days to heading } \\
\text { (day) }\end{array}$} & \multicolumn{2}{|c|}{$\begin{array}{l}\text { Days to maturity } \\
\text { (day) }\end{array}$} & \multicolumn{2}{|c|}{$\begin{array}{c}\text { No. of } \\
\text { spikes / plant }\end{array}$} & \multicolumn{2}{|c|}{$\begin{array}{c}\text { No. of } \\
\text { grains / spike }\end{array}$} & \multicolumn{2}{|c|}{$\begin{array}{l}\text { 1000-grain weight } \\
\text { (g) }\end{array}$} & \multicolumn{2}{|c|}{$\begin{array}{c}\text { Grain yield/plant } \\
\text { (g) }\end{array}$} & \multicolumn{2}{|c|}{$\begin{array}{c}\text { Grain protein content } \\
(\%)\end{array}$} \\
\hline & & $\overline{S_{1}}$ & $\mathbf{S}_{2}$ & $\mathrm{~S}_{1}$ & $\mathbf{S}_{2}$ & $\mathrm{~S}_{1}$ & $\mathbf{S}_{2}$ & $\mathrm{~S}_{1}$ & $\mathrm{~S}_{2}$ & $\overline{S_{1}}$ & $\mathbf{S}_{2}$ & $\mathrm{~S}_{1}$ & $\mathrm{~S}_{2}$ & $\mathrm{~S}_{1}$ & $\mathbf{S}_{2}$ \\
\hline Replicates & 2 & 3.53 & 2.69 & 2.81 & 3.58 & 0.28 & 0.13 & 1.51 & 0.37 & 0.33 & 0.14 & 1.30 & 2.20 & 0.01 & 0.02 \\
\hline Genotypes & 35 & $65.16^{* * *}$ & $16.47^{* *}$ & $46.86 * *$ & $15.25 * *$ & $4.96 * *$ & $6.39 * *$ & $284.46 * *$ & $246.50 * *$ & $1.04 * *$ & $0.90 * *$ & $63.57 * *$ & $43.57 * *$ & $0.90 * *$ & $1.52 * *$ \\
\hline Parents & 7 & $133.38 * *$ & $48.74^{* *}$ & $66.95^{* *}$ & $20.17 * *$ & $6.20 * *$ & $8.54 * *$ & $131.46 * *$ & $107.11 \% *$ & $1.83 * *$ & $1.38 * *$ & $26.07 * *$ & $15.67^{* *}$ & $0.92 * *$ & $2.05 * *$ \\
\hline Crosses & 27 & $48.65^{* *}$ & $8.24 * *$ & $41.87 * *$ & $13.84 * *$ & $4.63 * *$ & $5.88 * *$ & $304.96 * *$ & $279.83 * *$ & $0.78 * *$ & $0.73 * *$ & $46.37 * *$ & $33.58 * *$ & $0.81 * *$ & $1.33 * *$ \\
\hline P. vs. C. & 1 & $33.48 * *$ & $12.60 * *$ & $40.68 * *$ & $18.67 * *$ & $5.03 * *$ & $4.99 * *$ & $802.16 * *$ & $322.28 * *$ & $2.39 * *$ & $1.94 \% *$ & $790.40 * *$ & $508.63 * *$ & $3.29 * *$ & $2.70 * *$ \\
\hline Error & 70 & 1.43 & 0.97 & 5.21 & 2.49 & 0.49 & 0.48 & 0.86 & 0.76 & 0.12 & 0.10 & 1.45 & 0.94 & 0.09 & 0.04 \\
\hline GCA & 7 & $284.75^{* *}$ & $70.29 * *$ & $187.73 * *$ & $55.81 * *$ & $16.89 * *$ & $25.02 * *$ & $674.57 * *$ & $634.51 * *$ & $2.72 * *$ & $2.75^{* *}$ & $60.98 * *$ & $42.54 * *$ & $0.99 * *$ & $1.60 * *$ \\
\hline SCA & 28 & $10.26^{* *}$ & $3.01 * *$ & $11.64 * *$ & $5.10 * *$ & $1.97 * *$ & $1.73 * *$ & $186.94 * *$ & $149.50 * *$ & $15.54 * *$ & $0.43 * *$ & $64.22 * *$ & $43.83 * *$ & $0.88 * *$ & $1.50^{* *}$ \\
\hline GCA / SCA & & 27.74 & 23.34 & 16.13 & 10.93 & 8.56 & 14.47 & 284.46 & 246.50 & 0.17 & 6.33 & 0.95 & 0.97 & 1.13 & 1.07 \\
\hline
\end{tabular}

*and**: Significant at 0.05 and 0.01 levels of probability, respectively. $\quad \mathrm{S}_{1}$ : Normal sowing $\left(20^{\text {th }}\right.$ November $)$ and $\mathrm{S}_{2}$ : Late sowing $\left(20^{\text {th }}\right.$ December $)$. 
(2006), Motawea (2006), Salama and Salem (2006), El-Shamarka et al. (2009), El-Moselhy (2009), Sedek (2009), Rizkalla et al. (2012), Abd-Allah (2013), Abdallah et al. (2015) and Qabil (2017) who found that both general and specific combining ability variances were significant and involved in the genetics of the studied characters.

GCA/SCA ratio was more than unity for days to heading, days to maturity, number of spikes/plant, number of grains/ spike and protein content under both sowing dates as well as 1000grain weight under the late sowing date, indicating the predominance of additive gene action in the inheritance of these characters. Consequently, phenotypic selection procedure would be very successful in improving these characters. Similar results were recorded by Ismail et al. (2006), El-Shamarka et al. (2009), Rizkalla et al. (2012), Abd-Allah (2013), Abdallah et al. (2015) and Qabil (2017). On the other hand, mean square due to SCA was much higher in magnitude than those of GCA $(\mathrm{CGA} / \mathrm{SCA}<1)$ for 1000 -grain weight under the normal sowing date. So, hybrid breeding procedure would be successful in improving this character. Furthermore, GCA/SCA ratio was near to unity for grain yield/ plant under the two sowing dates, revealing complete dominance mode of inheritance. El-Moselhy (2009) and ElShamarka et al. (2009) reported that the GCA/ SCA ratio was near to unity for grain yield/plant.

\section{Mean Performance}

Mean performance of earliness characters, yield, its components and protein content for parental wheat cultivars and their $F_{1}$ crosses under the normal and late sowing dates are presented in Table 3.

Under the two sowing dates for earliness characters, the earliest wheat genotypes in days to heading were Gemmeiza 7, Gemmeiza 11, (Gemmeiza $7 \times$ Gemmeiza 11), (Gemmeiza $7 \times$ Sids 12), (Gemmeiza $7 \times$ Giza 168), (Gemmeiza $7 \times$ Giza 171), (Gemmeiza $11 \times$ Sids 12), (Gemmeiza $11 \times$ Giza 168), (Gemmeiza $11 \times$ Giza 171) and (Sids $12 \times$ Giza 168) as well as the genotypes Gemmeiza 7, Gemmeiza 11, Sids 12, (Gemmeiza $7 \times$ Gemmeiza 11), (Gemmeiza $7 \times$ Sids 12) and (Gemmeiza $11 \times$ Sids 12) in days to maturity. These genotypes were promising ones for both early heading and maturity.

Under the normal sowing date for yield and its components (Table 3), the genotypes Gemmeiza 12, Misr 1, Giza 171, (Gemmeiza $12 \times$ Misr 1) and (Misr $\times$ Giza 171) gave the highest values for number of spikes/plant. Moreover, the greatest genotypes in their number of grains/ spike were Gemmeiza 11, Sids 12, (Gemmeiza 7 $\times$ Sids 12$)$, $($ Gemmeiza $9 \times$ Sids 12$)$, $($ Sids $12 \times$ Misr 1) and (Sids $12 \times$ Giza 171). Furthermore, the heaviest genotypes in 1000-grain weight were Gemmeiza 11, Giza 171, (Gemmeiza $7 \times$ Giza 171), (Gemmeiza $11 \times$ Misr 1) and (Gemmeiza $11 \times$ Giza 171). The genotypes Gemmeiza 11, Misr 1, Giza 171(Gemmeiza $7 \times$ Sids 12), (Gemmeiza $7 \times$ Giza 171), (Gemmeiza $11 \times$ Misr 1), (Gemmeiza $11 \times$ Giza 171), (Gemmeiza $12 \times$ Giza 168), (Sids $12 \times$ Misr 1$)$, (Sids $12 \times$ Gize 171), (Misr $1 \times$ Giza 168) and (Misr $1 \times$ Giza 171) had high mean values for grain yield / plant.

Under the late sowing date, it is interest to note that, the highest mean values in yield components were observed for number of spikes/plant in genotypes Gemmeiza 12, Misr 1, Giza 171, (Gemmeiza $12 \times$ Misr 1) and (Misr $\times$ Giza 171); number of grains/spike for genotypes Gammeiza 11, Sids 12, (Gemmeiza $7 \times$ Sids 12), (Gemmeiza $9 \times$ Gemmeiza 11), (Gemmeiza 12 $\times$ Sids 12) and (Sids $12 \times$ Giza 171); 1000-grain weight for genotypes Gemmeiza 11, Giza 171, (Gemmeiza $7 \times$ Giza 171), (Gemmeiza $11 \times$ Misr 1) and (Gemmeiza $11 \times$ Giza 171) and (Gemmeiza $12 \times$ Giza 171) as well as grain yield/plant for genotypes Gemmeiza 11, Gemmeiza 12, Misr 1, Giza 171, (Gemmeiza 7 $\times$ Sids 12), (Gemmeiza 7 × Giza 171), (Gemmeiza $11 \times$ Misr 1), (Gemmeiza $11 \times$ Giza 171), (Gemmeiza $12 \times$ Giza 168), (Sids $12 \times$ Misr 1), (Sids $12 \times$ Gize 171), (Misr $1 \times$ Giza 168) and (Misr $1 \times$ Giza 171). Hereby these genotypes were more tolerant to late sowing date and could be used for selecting new recombinants characterized by greater yield, its components and tolerant to heat stress.

The yield reduction percentage and heat sensitivity index (HSI) are shown in Table (3), the parental wheat cultivar Gemmeiza 12 and $\mathrm{F}_{1}$ crosses (Gemmeiza $7 \times$ Gemmeiza 11), 
Table 3. Mean performance of parental genotypes and their $F_{1}$ crosses for earliness characters, yield, its components and grain protein content $(\%)$ under the two sowing dates

\begin{tabular}{|c|c|c|c|c|c|c|c|c|c|c|c|c|c|c|c|c|}
\hline \multirow[t]{2}{*}{ Genotype } & \multicolumn{2}{|c|}{ Days to heading (day) } & \multicolumn{2}{|c|}{ Days to maturity (day) } & \multicolumn{2}{|c|}{ No. of spikes/plant } & \multicolumn{2}{|c|}{ No. of grains/spike } & \multicolumn{2}{|c|}{ 1000-grain weight (g) } & \multicolumn{2}{|c|}{ Grain yield / plant (g) } & \multirow{2}{*}{$\begin{array}{l}\text { Reduction } \\
(\%)\end{array}$} & \multirow[t]{2}{*}{ HSI } & \multicolumn{2}{|c|}{ Protein content (\%) } \\
\hline & $S_{1}$ & $\mathbf{S}_{2}$ & $S_{1}$ & $\mathbf{S}_{2}$ & $\mathbf{S}_{1}$ & $\mathbf{S}_{2}$ & $\mathbf{S}_{1}$ & $\mathbf{S}_{2}$ & $S_{1}$ & $\mathrm{~S}_{2}$ & $S_{1}$ & $\mathrm{~S}_{2}$ & & & $\mathrm{~S}_{1}$ & $\mathrm{~S}_{2}$ \\
\hline Gemmeiza $7\left(\mathbf{P}_{1}\right)$ & 90.3 & 88.7 & 146.0 & 125.0 & 11.6 & 12.9 & 72.7 & 59.5 & 54.3 & 46.9 & 18.0 & 13.2 & 26.6 & 1.11 & 9.56 & 10.98 \\
\hline Gemmeiza $9\left(\mathbf{P}_{2}\right)$ & 110.3 & 97.7 & 158.3 & 129.7 & 11.8 & 12.8 & 77.1 & 57.3 & 49.6 & 39.3 & 19.9 & 14.8 & 25.6 & 1.06 & 10.66 & 12.24 \\
\hline Gemmeiza $11\left(\mathrm{P}_{3}\right)$ & 94.0 & 86.0 & 146.3 & 125.3 & 10.2 & 10.9 & 82.1 & 70.4 & 60.0 & 47.4 & 24.8 & 18.4 & 25.80 & 1.07 & 9.89 & 11.56 \\
\hline Sids $12\left(P_{5}\right)$ & 96.0 & 86.7 & 146.7 & 126.7 & 8.5 & 10.8 & 86.2 & 71.7 & 55.5 & 41.8 & 23.5 & 17.4 & 25.9 & 1.08 & 10.97 & 13.13 \\
\hline Misr $1\left(\mathbf{P}_{6}\right)$ & 106.7 & 91.0 & 156.0 & 128.7 & 12.4 & 15.6 & 66.1 & 55.4 & 50.6 & 41.0 & 24.4 & 17.8 & 27.0 & 1.12 & 11.13 & 13.18 \\
\hline Giza $168\left(\mathbf{P}_{7}\right)$ & 98.3 & 86.7 & 148.3 & 129.0 & 11.4 & 11.8 & 73.0 & 60.1 & 43.5 & 34.0 & 19.5 & 14.7 & 24.6 & 1.02 & 10.45 & 12.66 \\
\hline Giza $171\left(\mathbf{P}_{8}\right)$ & 101.7 & 93.0 & 153.0 & 133.0 & 13.0 & 14.5 & 70.6 & 64.2 & 63.2 & 48.1 & 26.1 & 19.6 & 24.9 & 1.03 & 10.87 & 13.29 \\
\hline Gemmeiza $7 \times$ Gemmeiza 9 & 99.0 & 92.3 & 153.0 & 129.3 & 10.4 & 11.2 & 89.3 & 69.2 & 60.9 & 46.4 & 29.2 & 19.8 & 32.1 & 1.34 & 11.08 & 13.18 \\
\hline Gemmeiza $7 \times$ Gemmeiza 12 & 95.3 & 90.0 & 150.7 & 128.7 & 10.7 & 12.9 & 64.6 & 55.6 & 46.1 & 36.9 & 27.1 & 21.6 & 20.2 & 0.84 & 11.29 & 12.88 \\
\hline Gemmeiza $7 \times$ Sids 12 & 92.7 & 87.0 & 145.0 & 126.7 & 7.8 & 11.1 & 94.5 & 81.5 & 50.8 & 42.1 & 31.3 & 25.0 & 20.1 & 0.83 & 10.24 & 12.45 \\
\hline Gemmeiza $7 \times$ Misr 1 & 98.0 & 89.0 & 154.0 & 128.0 & 11.3 & 12.6 & $\mathbf{7 5 . 4}$ & 63.7 & 55.2 & 45.5 & 29.7 & 24.3 & 18.1 & 0.75 & 12.13 & 14.13 \\
\hline Gemmeiza $7 \times$ Giza 168 & 95.3 & 87.0 & 147.7 & 130.0 & 10.3 & 11.3 & 75.2 & 73.3 & 48.8 & 31.8 & 26.5 & 20.1 & 24.1 & 1.00 & 10.87 & 13.50 \\
\hline Gemmeiza $7 \times$ Giza 171 & 94.3 & 90.0 & 150.0 & 132.3 & 10.6 & 11.4 & 81.7 & 67.6 & 61.9 & 48.0 & 33.1 & 25.4 & 23.2 & 0.96 & 10.66 & 11.19 \\
\hline Gemmeiza $9 \times$ Gemmeiza 11 & 99.0 & 89.3 & 153.7 & 127.7 & 11.0 & 11.9 & 85.1 & $\mathbf{7 8 . 2}$ & 58.3 & 46.9 & 28.6 & 22.9 & 19.9 & 0.83 & 11.08 & 13.08 \\
\hline Gemmeiza $9 \times$ Gemmeiza 12 & 104.0 & 92.0 & 156.0 & 129.0 & 12.1 & 12.9 & 61.1 & 49.8 & 45.5 & 35.2 & 30.9 & 22.2 & 28.1 & 1.17 & 9.82 & 12.66 \\
\hline Gemmeiza $9 \times$ Sids 12 & 101.0 & 90.0 & 155.3 & 128.7 & 10.4 & 11.7 & 94.9 & 72.8 & $\mathbf{5 8 . 1}$ & 46.1 & 23.6 & 17.8 & 24.5 & 1.02 & 11.10 & 13.50 \\
\hline Gemmeiza $9 \times$ Misr 1 & 105.3 & 91.7 & 158.0 & 133.7 & 12.4 & 13.1 & 60.3 & 45.8 & 59.4 & 47.2 & 26.2 & 18.0 & 31.2 & 1.30 & 10.87 & 13.09 \\
\hline Gemmeiza $9 \times$ Giza 168 & 100.3 & 90.7 & $\mathbf{1 5 4 . 0}$ & 132.3 & 11.4 & 12.2 & $\mathbf{7 8 . 4}$ & 66.2 & 43.4 & 32.6 & 25.6 & 18.7 & 26.9 & 1.12 & 11.50 & 13.93 \\
\hline Gemmeiza $9 \times$ Giza 171 & 103.3 & 92.3 & 155.7 & 132.7 & 11.6 & 12.1 & 80.8 & 67.6 & 60.4 & 46.9 & 26.1 & 18.6 & 28.7 & 1.19 & 10.66 & 13.06 \\
\hline Gemmeiza $11 \times$ Sids 12 & 93.7 & 87.0 & 145.3 & 127.0 & 8.8 & 9.2 & 82.8 & 75.0 & 56.8 & 47.4 & 27.1 & 20.1 & 25.8 & 1.07 & 11.82 & 12.13 \\
\hline Gemmeiza $11 \times$ Misr 1 & 99.7 & 90.3 & 155.7 & 129.3 & 11.5 & 14.4 & 75.2 & 58.8 & 62.6 & 49.4 & 34.4 & 25.5 & 25.8 & 1.07 & 10.87 & 12.87 \\
\hline Gemmeiza $11 \times$ Giza 168 & 95.0 & 87.3 & 150.7 & 128.7 & 10.1 & 11.2 & 78.1 & 63.3 & 55.8 & 43.6 & 27.8 & 22.2 & 20.1 & 0.83 & 10.24 & 11.77 \\
\hline Gemmeiza $11 \times$ Giza 171 & 94.7 & 88.3 & 148.0 & 128.7 & 11.5 & 12.1 & 91.5 & 74.0 & 63.5 & 51.1 & 34.9 & 27.9 & 20.0 & 0.83 & 10.88 & 12.45 \\
\hline Gemmeiza $12 \times$ Sids 12 & 98.7 & 88.0 & 154.0 & 127.3 & 10.7 & 12.9 & 90.0 & 80.1 & 58.6 & 43.9 & 27.2 & 21.8 & 19.8 & 0.82 & 10.66 & 12.45 \\
\hline Gemmeiza $12 \times$ Misr 1 & 104.7 & 90.0 & 156.7 & 128.0 & 13.7 & 14.9 & 77.1 & 54.7 & 57.7 & 44.5 & 30.6 & 22.2 & 27.4 & 1.14 & 10.87 & 12.45 \\
\hline Gemmeiza $12 \times$ Giza 168 & 99.3 & 90.3 & 152.0 & 129.0 & 10.4 & 11.6 & $\mathbf{7 5 . 0}$ & 63.0 & $\mathbf{5 5 . 4}$ & 43.2 & 33.0 & 25.7 & 22.1 & 0.92 & 11.10 & 12.66 \\
\hline Gemmeiza $12 \times$ Giza 171 & 100.3 & 91.3 & 154.7 & 129.3 & 11.3 & 13.8 & 83.4 & 55.2 & 57.2 & 48.6 & 28.7 & 22.5 & 21.6 & 0.90 & 10.87 & 13.11 \\
\hline Sids $12 \times$ Misr 1 & 98.7 & 88.7 & 149.3 & 127.7 & 10.4 & 13.7 & 99.6 & 71.0 & 56.8 & 42.8 & 33.0 & 24.5 & 25.7 & 1.07 & 12.13 & 13.93 \\
\hline Sids $12 \times$ Giza 168 & 95.0 & 87.7 & 152.0 & 127.7 & 11.3 & 11.5 & 83.5 & 66.2 & 56.2 & 40.0 & 28.9 & 22.6 & 21.7 & 0.90 & 10.66 & 12.66 \\
\hline Sids $12 \times$ Giza 171 & 97.0 & 88.7 & 152.3 & 129.7 & 10.0 & 12.0 & 101.6 & 87.8 & 57.4 & 47.0 & 33.6 & 24.3 & 27.6 & 1.15 & 10.87 & 12.15 \\
\hline Misr 1 × Giza 168 & 101.0 & 88.7 & 154.0 & 129.3 & 10.2 & 13.2 & 77.4 & 63.2 & 53.2 & 43.6 & 32.5 & 25.5 & 21.5 & 0.89 & 11.16 & 12.03 \\
\hline Misr $1 \times$ Giza 171 & 102.7 & 90.3 & 156.0 & 133.3 & 13.4 & 15.9 & 75.9 & 65.6 & 54.4 & 49.6 & 32.9 & 26.6 & 19.1 & 0.79 & 11.29 & 13.50 \\
\hline Giza $168 \times$ Giza 171 & 107.0 & 90.3 & 154.0 & 132.0 & 11.4 & 12.4 & 80.6 & 75.6 & $\mathbf{5 0 . 7}$ & 42.1 & 19.5 & 14.1 & 27.6 & 1.15 & 10.66 & 13.05 \\
\hline $\mathbf{L S D}_{0.05}$ & 1.95 & 1.60 & 3.72 & 2.57 & 1.14 & 1.13 & 1.51 & 1.42 & 0.56 & 0.50 & 1.96 & 1.58 & & & 0.42 & 0.33 \\
\hline $\operatorname{LSD}_{0.01}$ & 2.59 & 2.13 & 4.93 & 3.41 & 1.52 & 1.49 & 2.00 & 1.89 & 0.74 & 0.67 & 2.60 & 2.10 & & & 0.56 & 0.44 \\
\hline
\end{tabular}


(Gemmeiza 7× Gemmeiza 12), (Gemmeiza $7 \times$ Sids 12), (Gemmeiza $7 \times$ Misr 1), (Gemmeiza 9 $\times$ Gemmeiza 11), (Gemmeiza $11 \times$ Giza 168), (Gemmeiza $11 \times$ Giza 171), (Gemmeiza $12 \times$ Sids 12) and (Misr $1 \times$ Giza 171) proffered the lowest reduction percentage in wheat grain yield with values $20.7 \%, 20.8 \%, 20.2 \%, 20.1 \%$, $18.1 \%, \quad 19.9 \%, 20.1 \%, 20.0 \%, \quad 19.8 \%$ and $19.1 \%$, respectively. Also, the former genotypes attained the lowest HSI values $(<1.0)$. Thus, these genotypes could be considered as more tolerant to heat stress as created by late sowing date. On the other hand, the local parental cultivars Gemmeiza 7 and Misr 1 as well as the $\mathrm{F}_{1}$ crosses (Gemmeiza $7 \times$ Gemmeiza 9), (Gemmeiza $9 \times$ Gemmeiza 12), (Gemmeiza $9 \times$ Misr 1), (Gemmeiza $9 \times$ Giza 168), (Gemmeiza $9 \times$ Giza 171), (Gemmeiza 11x Gemmeiza 12), (Gemmeiza $12 \times$ Misr 1), (Sids $12 \times$ Giza 171) and (Giza $168 \times$ Giza 171) had high yield reduction percentage in grain yield with values of $26.6 \%, 27.0 \%, 32.1 \%, 28.1 \%, 31.2 \%, 26.9 \%$, $28.7 \%, 26.4 \%, 27.4 \%, 27.6 \%$ and $27.6 \%$, respectively. In addition, the previous genotypes exhibited the highest HSI values $(>1.0)$. Therefore, these genotypes were more sensitive to late sowing date (heat stress). Similar results were recorded by El-Moselhy (2009), Abdallah et al. (2015) and Kumar et al. (2018).

For protein content as shown in Table 3, the highest values of the respective protein content were obtained from the genotypes Gemmeiza 12, Sids 12, Misr 1, Giza 171, (Gemmeiza $7 \times$ Misr 1), (Gemmeiza $9 \times$ Giza 168), (Gemmeiza $11 \times$ Sids 12) and (Sids $12 \times$ Misr 1) under the normal sowing date as well as Gemmeiza 12, Sids 12, Misr 1, Giza 168, Giza 171, (Gemmeiza $7 \times$ Misr 1), (Gemmeiza $9 \times$ Giza 168) and (Sids $12 \times$ Misr 1) under the late sowing date. These results suggest that these genotypes could be used through wheat breeding programs to improve protein content.

\section{General and Specific Combining Ability}

Estimates of GCA effects (gi) for earliness characters, yield, its components and protein content under both sowing dates are presented in Table 4. The wheat cultivars Gemmeiza 7, Gemmeiza 11 and Sids 12 for earliness characters under the two sowing dates as well as Giza 168 for days to heading under the late sowing date exhibited negative and highly significant GCA effects. These parents are considered to be good general combiners and can be used in breeding programs for improving earliness.

For number of spikes/plant, results demonstrate that GCA effects were positive and significant for the local cultivars Gemmeiza 12, Misr 1 and Giza 171 under both sowing dates as well as Gemmeiza 9 under the normal sowing date. Positive and highly significant GCA effects have been registered for number of grains/spike by the local cultivars Gemmeiza 11, Sids 12 and Giza 171 under both sowing dates. Moreover, 1000- grain weight had positive and significant GCA effects for the local cultivars Gemmeiza 11 and Giza 171 under the two sowing dates as well as Misr 1 under the late sowing date. The wheat cultivars Gemmeiza 12, Misr 1 and Giza 171 under normal and late sowing dates as well as Gemmeiza 11 under the late sowing date were the best combiners for grain yield/plant as they recorded positive and significant GCA effects for this character. The greatest positive and significant GCA effect for protein content was given by Misr 1 under the two sowing dates, Sids 12 under the normal sowing date and Gemmeiza 9 under the late sowing date. Thus, these cultivars could be expressed as excellent combiners for improving yield, its components and protein content.

The SCA effects for all studied characters under the normal and the late sowing dates are illustrated in Table 5. Negative and significant specific combining ability effects were obtained in the crosses (Gemmeiza $9 \times$ Giza 168), (Gemmeiza $11 \times$ Giza 171) and (Sids $12 \times$ Giza 168) for days to heading as well as (Sids $12 \times$ Misr 1) for days to maturity under the normal sowing date. Also, negative and significant SCA effect was attained by the wheat cross (Gemmeiza $9 \times$ Gemmeiza 11) for days to heading under the late sowing date. These crosses involved at least one of good earlier combiner parent. The previous results suggesting low sensitivity of these crosses by the changes in sowing dates. Whereas, all crosses had positive or non-significant SCA effects under the late sowing date for days to maturity. 
Table 4. Estimation of general combining ability effects for the parental wheat cultivars for earliness characters, yield, its components and grain protein content $(\%)$ under the two sowing dates

\begin{tabular}{|c|c|c|c|c|c|c|c|c|c|c|c|c|c|c|}
\hline \multirow[t]{2}{*}{ Genotype } & \multicolumn{2}{|c|}{$\begin{array}{l}\text { Days to heading } \\
\text { (day) }\end{array}$} & \multicolumn{2}{|c|}{$\begin{array}{l}\text { Days to maturity } \\
\text { (day) }\end{array}$} & \multicolumn{2}{|c|}{$\begin{array}{l}\text { No. of spikes / } \\
\text { plant }\end{array}$} & \multicolumn{2}{|c|}{$\begin{array}{l}\text { No. of grains / } \\
\text { spike }\end{array}$} & \multicolumn{4}{|c|}{$\begin{array}{l}\text { 1000-grain weight Grain yield / plant } \\
\text { (g) }\end{array}$} & \multicolumn{2}{|c|}{$\begin{array}{c}\text { Grain protein content } \\
(\%)\end{array}$} \\
\hline & $\mathbf{S}_{1}$ & $\mathbf{S}_{2}$ & $\mathbf{S}_{1}$ & $\mathbf{S}_{\mathbf{2}}$ & $\mathbf{S}_{1}$ & $\mathbf{S}_{2}$ & $\mathbf{S}_{1}$ & $\mathbf{S}_{2}$ & $\mathbf{S}_{1}$ & $\mathbf{S}_{2}$ & $\mathbf{S}_{1}$ & $\mathbf{S}_{2}$ & $\mathbf{S}_{1}$ & $\mathbf{S}_{2}$ \\
\hline Gemmeiza 7 & $-4.43 * *$ & $-0.65 * *$ & $-3.22 * *$ & $-1.16^{* *}$ & $-0.58 * *$ & $-0.58 * *$ & $-1.22 * *$ & 0.33 & -0.04 & 0.01 & $-1.48 * *$ & $-0.95^{* *}$ & $-0.204 * *$ & $-0.245^{* *}$ \\
\hline Gemmeiza 9 & $4.17 * *$ & $2.71 * *$ & $3.45^{* *}$ & $1.14 * *$ & $0.41 *$ & -0.14 & $-1.52 * *$ & $-3.2 * *$ & -0.09 & -0.11 & $-1.78 * *$ & $-2.04 * *$ & -0.045 & $0.214^{* *}$ \\
\hline Gemmeiza 11 & $-3.23 * *$ & $-1.65^{* *}$ & $-2.48 * *$ & $-1.62 * *$ & $-0.60 * *$ & $-0.93 * *$ & $2.34 * *$ & $3.01 * *$ & $0.37 * *$ & $0.37 * *$ & 0.42 & $0.52 *$ & $-0.147^{*}$ & $-0.365 * *$ \\
\hline Gemmeiza 12 & $1.47 * *$ & $0.81 * *$ & $1.38^{*}$ & -0.42 & $0.46^{* *}$ & $0.62 * *$ & $-4.19 * *$ & $-4.01 * *$ & $-0.36^{* *}$ & $-0.34 * *$ & $0.64 *$ & $0.71 * *$ & -0.023 & -0.063 \\
\hline Sids 12 & $-2.23 * *$ & $-1.61 * *$ & $-2.12 * *$ & $-1.33 * *$ & $-1.25 * *$ & $-0.83 * *$ & $10.00^{* *}$ & $8.15 * *$ & 0.12 & 0.02 & 0.38 & 0.30 & $0.151^{*}$ & 0.070 \\
\hline Misr 1 & $3.23 * *$ & $0.41^{*}$ & $2.78^{* *}$ & 0.54 & $0.90^{* *}$ & $1.69 * *$ & $-4.62 * *$ & $-6.27 * *$ & 0.06 & $0.14 *$ & $2.03 * *$ & $1.40 * *$ & $0.370^{* *}$ & $0.352 * *$ \\
\hline Giza 168 & -0.13 & $-1.11 * *$ & -0.68 & 0.58 & -0.05 & $-0.50 * *$ & $-2.51 * *$ & $-0.54 *$ & $-0.44 * *$ & $-0.46^{* *}$ & $-1.52 * *$ & $-0.97 * *$ & -0.078 & 0.009 \\
\hline Giza 171 & $1.17 * *$ & $1.08^{* *}$ & 0.88 & $2.28 * *$ & $0.71 * *$ & $0.66 * *$ & $1.72 * *$ & $2.54 * *$ & $0.38^{* *}$ & $0.38^{* *}$ & $1.30^{* *}$ & $1.04 * *$ & -0.024 & 0.026 \\
\hline S.E.(gi-gj) & 0.20 & 0.17 & 0.58 & 0.40 & $\cdot .18$ & 0.17 & 0.16 & 0.15 & 0.08 & 0.08 & 0.21 & 0.17 & 0.078 & 0.052 \\
\hline
\end{tabular}

*, **: Significant at 0.05 and 0.01 levels of probability, respectively. S1: Normal sowing (20 $0^{\text {th }}$ November) and S2: Late sowing (20 $0^{\text {th }}$ December). 
Table 5. Estimation of specific combining ability effects for earliness characters, yield, its components and grain protein content (\%) under the two sowing dates

\begin{tabular}{|c|c|c|c|c|c|c|c|c|c|c|c|c|c|c|}
\hline \multirow[t]{2}{*}{ Genotype } & \multicolumn{2}{|c|}{$\begin{array}{l}\text { Days to heading } \\
\text { (day) }\end{array}$} & \multicolumn{2}{|c|}{$\begin{array}{l}\text { Days to maturity } \\
\text { (day) }\end{array}$} & \multicolumn{2}{|c|}{$\begin{array}{l}\text { No. of spikes / } \\
\text { plant }\end{array}$} & \multicolumn{2}{|c|}{$\begin{array}{l}\text { No. of grains / } \\
\text { spike }\end{array}$} & \multicolumn{2}{|c|}{$\begin{array}{l}\text { 1000-grain weight } \\
\text { (g) }\end{array}$} & \multicolumn{2}{|c|}{$\begin{array}{c}\text { Grain yield / plant } \\
(\mathrm{g})\end{array}$} & \multicolumn{2}{|c|}{$\begin{array}{c}\text { Grain protein content } \\
(\%)\end{array}$} \\
\hline & $\mathbf{S}_{1}$ & $\mathbf{S}_{2}$ & S1 & S2 & $\mathbf{S}_{1}$ & $\mathbf{S}_{2}$ & $\mathbf{S}_{1}$ & $\mathbf{S}_{2}$ & $\mathbf{S}_{1}$ & $\mathbf{S}_{2}$ & $\mathbf{S}_{1}$ & $\mathbf{S}_{2}$ & $\mathrm{~S}_{1}$ & $\mathbf{S}_{2}$ \\
\hline Gemmeiza $7 \times$ Gemmeiza 9 & 0.27 & 0.66 & 0.79 & 0.32 & -0.45 & -0.56 & -0.45 & $5.80 * *$ & $0.74 * *$ & $0.40^{*}$ & $4.96 * *$ & $1.91 * *$ & $0.453 *$ & $0.453 * *$ \\
\hline Gemmeiza $7 \times$ Gemmeiza 11 & 0.00 & 0.02 & -2.95 & -1.58 & $-0.97 *$ & -0.84 & $-0.97 *$ & 0.07 & -0.08 & 0.06 & $-6.34 * *$ & $-4.54 * *$ & -0.075 & $0.946^{* *}$ \\
\hline Gemmeiza $7 \times$ Gemmeiza 12 & -0.70 & 0.22 & 0.52 & 1.22 & -0.14 & 0.38 & -0.14 & $-6.97 * *$ & $-0.48 *$ & -0.32 & 0.44 & 0.92 & $0.642 *$ & $0.429 * *$ \\
\hline Gemmeiza $7 \times$ Sids 12 & 0.33 & -0.34 & -1.65 & 0.12 & $-1.36 *$ & 0.07 & $-1.36 *$ & $6.80^{* *}$ & $-0.48 *$ & -0.17 & $4.85^{* *}$ & $4.81 * *$ & $-0.582 * *$ & -0.134 \\
\hline Gemmeiza $7 \times$ Misr 1 & 0.20 & -0.38 & 2.45 & -0.41 & -0.04 & $-0.99 *$ & -0.04 & $3.35 * *$ & 0.01 & 0.06 & $1.64 *$ & $2.92 * *$ & $1.084 * *$ & $1.259 * *$ \\
\hline Gemmeiza $7 \times$ Giza 168 & 0.90 & -0.84 & -0.41 & 1.56 & -0.05 & -0.07 & -0.05 & $7.22 * *$ & -0.13 & $-0.71 * *$ & $1.93 *$ & 1.13 & 0.277 & $0.972^{* *}$ \\
\hline Gemmeiza $7 \times$ Giza 171 & -1.40 & -0.04 & 0.35 & 2.19* & -0.54 & $-1.16 *$ & -0.54 & $-1.52 \%$ & 0.37 & 0.06 & $5.77 * *$ & $4.39 * *$ & 0.013 & $-1.350 * *$ \\
\hline Gemmeiza $9 \times$ Gemmeiza 11 & -0.93 & $-1.34 *$ & 0.72 & -0.88 & 0.21 & 0.49 & 0.21 & $12.18^{* *}$ & 0.06 & 0.09 & $2.47 * *$ & $3.53 * *$ & $0.396^{*}$ & $0.467 * *$ \\
\hline Gemmeiza $9 \times$ Gemmeiza 12 & -0.63 & -1.14 & -0.81 & -0.74 & 0.28 & -0.03 & 0.28 & $-9.20 * *$ & $-0.49 *$ & -0.37 & $4.49 * *$ & $2.69 * *$ & $-0.986 * *$ & -0.255 \\
\hline Gemmeiza $9 \times$ Sids 12 & 0.07 & -0.71 & 2.02 & -0.18 & 0.29 & 0.23 & 0.29 & $1.57^{*}$ & 0.29 & 0.36 & $-2.58 * *$ & $-1.37^{*}$ & 0.118 & $0.457^{* *}$ \\
\hline Gemmeiza $9 \times$ Misr 1 & -1.07 & -1.08 & -0.21 & 2.96* & 0.11 & $-0.89 *$ & 0.11 & $-10.98 * *$ & $0.47^{*}$ & 0.35 & $-1.58 *$ & $-2.27 * *$ & -0.330 & -0.235 \\
\hline Gemmeiza $9 \times$ Giza 168 & $-2.70 * *$ & -0.54 & -0.75 & 1.59 & 0.06 & 0.36 & 0.06 & $3.73^{* *}$ & $-0.62 *$ & $-0.51 *$ & 1.36 & 0.78 & $0.748^{* *}$ & $0.943^{* *}$ \\
\hline Gemmeiza $9 \times$ Giza 171 & -1.00 & -1.08 & -0.65 & 0.22 & -0.53 & $-0.90 *$ & -0.53 & $1.98 * *$ & 0.26 & 0.07 & -0.98 & $-1.34 *$ & -0.143 & 0.061 \\
\hline Gemmeiza $11 \times$ Gemmeiza 12 & 0.10 & -0.44 & 2.79 & 1.36 & -0.51 & 0.02 & -0.51 & $1.35 *$ & 0.21 & 0.29 & 0.88 & -0.39 & $0.584 * *$ & $0.339 *$ \\
\hline Gemmeiza $11 \times$ Sids 12 & 0.13 & 0.66 & -2.05 & 0.92 & -0.33 & $-1.49 * *$ & -0.33 & $-2.42 * *$ & -0.30 & 0.01 & -1.27 & $-1.59 *$ & $0.940 * *$ & $-0.334 *$ \\
\hline Gemmeiza $11 \times$ Misr 1 & 0.67 & $1.96 * *$ & $3.39^{*}$ & 1.39 & 0.22 & $1.16^{*}$ & 0.22 & $-4.17 * *$ & 0.33 & 0.10 & $4.42 * *$ & $2.67 * *$ & -0.229 & 0.124 \\
\hline Gemmeiza $12 \times$ Sids 12 & 0.43 & -0.81 & 2.75 & 0.06 & 0.47 & 0.66 & 0.47 & $9.71 * *$ & $0.62 *$ & 0.37 & -1.39 & -0.14 & -0.344 & $-0.316^{*}$ \\
\hline Gemmeiza $12 \times$ Misr 1 & 0.97 & -0.84 & 0.52 & -1.14 & $1.36^{*}$ & 0.17 & 1.36 & $-1.24 *$ & $0.58 *$ & 0.32 & 0.39 & -0.81 & -0.346 & $-0.598 * *$ \\
\hline Gemmeiza $12 \times$ Giza 168 & -1.00 & 1.02 & -0.68 & -0.18 & $-1.03 *$ & $-1.01 *$ & -1.03 & $1.30 * *$ & $0.85^{* *}$ & $0.78 * *$ & $6.31 * *$ & $5.08 * *$ & 0.326 & -0.040 \\
\hline Gemmeiza $12 \times$ Giza 171 & -1.30 & -0.18 & 0.42 & -1.54 & -0.82 & 0.04 & -0.82 & $-9.62 * *$ & 0.21 & $0.48^{*}$ & -0.76 & -0.18 & 0.045 & 0.388* \\
\hline Sids $12 \times$ Misr 1 & -1.33 & 0.26 & $-3.31 *$ & -0.58 & -0.23 & 0.36 & -0.23 & $2.87^{* *}$ & 0.01 & -0.22 & $3.08 * *$ & $1.96 * *$ & $0.729 * *$ & $0.744^{* *}$ \\
\hline Sids $12 \times$ Giza 168 & $-1.63 *$ & 0.79 & 2.82 & -0.61 & $1.59 * *$ & 0.42 & 1.59 & $-7.70 * *$ & $0.45^{*}$ & 0.10 & $2.48 * *$ & $2.43 * *$ & -0.288 & -0.173 \\
\hline Sids $12 \times$ Giza 171 & -0.93 & -0.41 & 1.59 & -0.31 & -0.40 & -0.24 & -0.40 & $10.82 * *$ & -0.25 & -0.05 & $4.34 * *$ & $2.07 * *$ & -0.132 & $-0.705^{* *}$ \\
\hline Misr 1 × Giza 168 & -1.10 & -0.24 & -0.08 & -0.81 & $-1.59 * *$ & -0.41 & -1.59 & $3.78^{* *}$ & $0.20^{*}$ & 0.34 & $4.46 * *$ & $4.19 * *$ & -0.007 & $-1.090^{* *}$ \\
\hline Misr $1 \times$ Giza 171 & -0.73 & -0.78 & 0.35 & 1.49 & 0.85 & $1.10^{*}$ & 0.85 & $3.03 * *$ & -0.49 & 0.09 & $1.97 *$ & $3.22 * *$ & 0.069 & $0.363^{*}$ \\
\hline Giza $168 \times$ Giza 171 & $6.97 * *$ & 0.76 & 1.82 & 0.12 & -0.23 & -0.24 & -0.23 & $7.37 * *$ & -0.36 & -0.06 & $-7.81 * *$ & $-6.88 * *$ & -0.109 & 0.256 \\
\hline S.E.(sij - sji) & 0.76 & 0.62 & 1.44 & 0.99 & 0.44 & 0.44 & 0.44 & 0.55 & 0.22 & 0.20 & 0.76 & 0.61 & 0.190 & 0.128 \\
\hline
\end{tabular}


Under the normal sowing date, positive and significant specific combining ability effects for number of spikes/plant were recorded in the crosses (Gemmeiza $12 \times$ Misr 1) and (Sids $12 \times$ Giza 168); for 1000-grain weight in the crosses (Gemmeiza $7 \times$ Gemmeiza 9), (Gemmeiza $9 \times$ Misr 1), (Gemmeiza $12 \times$ Sids 12), (Gemmeiza $12 \times$ Misr 1), (Gemmeiza $12 \times$ Giza 168), (Sids $12 \times$ Giza 168) and (Misr $1 \times$ Giza168); for grain yield / plant in the crosses (Gemmiza $7 \times$ Gemmeiza 9), (Gemmeiza $7 \times$ Sids 12), (Gemmeiza $7 \times$ Misr 1), (Gemmeiza $7 \times$ Giza 168), (Gemmeiza $7 \times$ Giza 171), (Gemmeiza $9 \times$ Gemmeiza 11), (Gemmeiza $9 \times$ Gemmeiza 12), (Gemmeiza $11 \times$ Misr 1), (Gemmeiza $11 \times$ Giza 171), (Gemmeiza $12 \times$ Giza 168), (Sids $12 \times$ Mirs 1), (Sids $12 \times$ Giza 168), (Sids $12 \times$ Giza 171), (Misr $1 \times$ Giza 168) and (Misr $1 \times$ Giza 171) as well as for protein content in the crosses (Gemmeiza $7 \times$ Gemmeiza 9), (Gemmeiza $7 \times$ Gemmeiza 12), (Gemmeiza 7 x Misr 1), (Gemmeiza $9 \times$ Gemmeiza 11), (Gemmeiza $9 \times$ Giza 168), (Gemmeiza 11 x Gemmeiza 12), (Gemmeiza $11 \times$ Sids 12$)$ and (Sids $12 \times$ Misr 1$)$. So, these crosses are the promising in practical breeding programs and could be grown under the normal sowing date.

Meantime under the late sowing date, positive and significant SCA effects for number of spikes/plant were showed in the two crosses (Gemmeiza $11 \times$ Misr 1) and (Misr $1 \times$ Giza 171); for number of grains/spike in the crosses (Gemmeiza $7 \times$ Gemmeiza 9), (Gemmeiza $7 \times$ Sids 12), (Gemmeiza $7 \times$ Misr 1), (Gemmeiza 7 $\times$ Giza 168), (Gemmeiza $9 \times$ Gemmeiza 11), (Gemmeiza $9 \times$ Sids 12), (Gemmeiza $9 \times$ Giza 168), (Gemmeiza 9 x Giza 171), (Gemmeiza 11 $\times$ Gemmeiza 12), (Gemmeiza $11 \times$ Giza 171), (Gemmeiza $12 \times$ Sids 12), (Gemmeiza $12 \times$ Giza168), (Sids $12 \times$ Misr1), (Sids $12 \times$ Giza 171), (Misr 1 x Giza 168), (Misr 1 x Giza 171) and (Giza $168 \times$ Giza 171); for1000-grain weight in the crosses (Gemmeiza $7 \times$ Gemmeiza 9), (Gemmeiza 12 x Giza 168) and (Gemmeiza $12 \times$ Giza 171); for grain yield/plant in the crosses (Gemmiza $7 \times$ Gemmeiza 9), (Gemmeiza $7 \times$ Sids 12), (Gemmeiza $7 \times$ Misr 1), (Gemmeiza $7 \times$ Giza 171), (Gemmeiza $9 \times$ Gemmeiza 11), (Gemmeiza $9 \times$ Gemmeiza 12), (Gemmeiza $11 \times$ Misr 1), (Gemmeiza $11 \times$ Giza168), (Gemmeiza $11 \times$ Giza 171),
(Gemmeiza $12 \times$ Giza 168), (Sids $12 \times$ Mirs 1), (Sids $12 \times$ Giza 168), (Sids $12 \times$ Giza 171), (Misr $1 \times$ Giza 168) and (Misr $1 \times$ Giza 171) as well as for protein content in the crosses (Gemmeiza $7 \times$ Gemmeiza 9), (Gemmeiza $7 \times$ Gemmeiza 11), (Gemmeiza $7 \times$ Gemmeiza 12), (Gemmeiza 7 x Misr 1), (Gemmeiza $7 \times$ Giza 168), (Gemmeiza $9 \times$ Gemmeiza 11), (Gemmeiza $9 \times$ Sids 12), (Gemmeiza $9 \times$ Giza 168), (Gemmeiza $11 \times$ Gemmeiza 12), (Gemmeiza $12 \times$ Giza 171), $($ Sids $12 \times$ Misr 1$)$ and (Misr $1 \times$ Giza 171). Thus, these crosses could be considered as tolerant to late sowing date. On the other hand, negative or not significant SCA effect were recorded by the all cross combinations under the normal sowing date for number of grains/spike. Positive and significant SCA effects were recorded by ElMoselhy (2009), Sedek (2009), Rizkalla et al. (2012), Abdallah et al. (2015) and Qabil (2017) for grain yield and its components.

\section{REFERENCES}

Abdallah, E., M.M.A. Ali, M.A.T. Yasin and A.H. Salem (2015). Combining ability and mode of gene action for earliness, yield and some yield attributes of bread wheat (Triticum aestivum L.) genotypes grown on different sowing dates. Zagazig J. Agric. Res., 42 (2): 215-235.

Abd-Allah, S.M.H. (2013). Heterosis and combining ability estimates of some quantitative traits in bread wheat under different nitrogen fertilization rates. Minufiya J. Agric. Res., 38 (6): 1455-1479.

Afridi, K., N.U. Khan, F. Mohammad, S.J.A. Shah, S. Gul, I.A. Khalil, M. Sajjad, S. Ali, I. Ali and S.M. Khan (2017). Inheritance pattern of earliness and yield traits in halfdiallel crosses of spring wheat. Can. J. Pl. Sci., 97: 865-880.

Ahmad, I., N. Mahmood, I. Khaliq and N. Khan (2016). Genetic analysis for five important morphological attributes in wheat (Triticum aestivum L.). J. Anim. and Pl. Sci., 26 (3): 725-730.

Anwar, J., M.A. Ali, M. Hussain, W. Sabir, M.A. Khan, M. Zulkiffal and M. Abdallah (2009). Assessment of yield criteria in bread wheat through correlation and path analysis. J. Anim. and Pl. Sci., 19 (4): 185-188. 
El-Moselhy, O.M.A. (2009). Diallel analysis of earliness characters, yield and yield components in bread wheat (Triticum aestivum L.). M.Sc. Thesis, Agron. Dept., Fac. Agric., Zagazig Univ., Egypt.

El-Shamarka, S.H.A., M.A. Abo Shereif, I.H. Darwesh, N.A. Gaafar and H.H. El-Fiki (2009). Combining ability for earliness, yield and yield components traits in wheat. Minufiya J. Agric. Res., 34 (1): 57-76.

FAO (2018). Production Year Book, 54, FAO, Rome.

Fisher, R.A. and R. Maurer (1978). Drought resistance in spring wheat cultivars. I. Grain yield responses. Aust. J. Agri. Res., 30: 801.

Gashaw, A., H. Mohamed and H. Singh (2007). Selection criterion for improved grain yield in Ethiopian durum wheat genotypes. Afri. Crop Sci. J., 5 (1): 25-31.

Griffing, J.B. (1956). Concept of general and specific combining ability in relation to diallel crossing system. Aust. J. Biol. Sci., 9: 463-493.

Hassan, M.I., E.A. Mohamed, M.A. El-Rawy and K.A. Amein (2016). Evaluating interspecific wheat hybrids based on heat and drought stress tolerance. J. Crop Sci. Biotech., 19 (1): 85-98.

Ismail, A.A., T.A. Ahmed, M.B. Tawfek and E.M.A. Khalifa (2006). Gene action and combining ability analysis of diallel crosses in bread wheat under moisture stress and non-stress conditions. Assiut J. Agric. Sci., 37 (2):17-33.

Khan, A. (2016). Performance of different bread wheat varieties for yield and yield attributes under diallel combinations. Annals of Agrarian Sci., 14: 25-34.

Kumar, A., Swati, A. Kumar, S. Adhikari and B. Prasad (2018). Genetic dissection of wheat genotypes using morpho-physiological traits for terminal heat tolerance. Int. J. Curr. Microbiol. App. Sci., 7 (2): 367-372.

Kumar, D., S.A. Kerkhi, G. Singh and J.B. Singh (2015). Estimates of genetic parameters for grain yield, agromorphological traits and quality attributes in bread wheat (Triticum aestivum L.). Ind. J. Agric. Sci., 85 (5): 622-627.

Kumar, S., P. Kumar and S.A. Kerkhi (2017). Genetic analysis for various yield components and gluten content in bread wheat (Triticum aestivum L.). J. Appl. and Nat. Sci., 9 (2): 879- 882.

Motawea, M.H. (2006). Inheritance of earliness, yield and yield components in wheat (Triticum aestivum L.). Assiut J. Agric. Sci., 37 (2):35-52.

Qabil, N. (2017). Genetic analysis of yield and its attributes in wheat (Triticum aestivum L.) under normal irrigation and drought stress conditions. Egypt. J. Agron., 39 (3): 337-356.

Rizkalla, A.A.B., A. Hussien, M.F. Al-Ansary, J.E. Nasseef and M.H.A. Hussein (2012). Combining ability and heterosis relative to RAPD marker in cultivated and newly hexaploid wheat varieties. Aust. J. Basic. and Appl. Sci., 6 (5): 215-224.

Salama, S.M. and Manal M. Salem (2006). Gene action and combining ability over sowing dates in bread wheat (Triticum aestivum L.). Egypt. J. Appl. Sci., 21 (118): 526-641.

Sedek, N.K. (2009). Effect of diallel size on the estimation of some genetic parameters in bread wheat (Triticum aestivum L.). M.Sc. Thesis, Agron. Dept., Fac. Agric., Zagazig Univ., Egypt.

Steel, R.G.D., J.H. Torrie and D.A. Diekey (1997). Principles and Procedures of Statistics. A Biometrical Approach $3^{\text {rd }}$ Ed McGraw-Hill Book Co. New York. 
القدرة على الإنتلاف للتبكير، المحصول ومكوناته فى بعض التراكيب الوراثية لقمح الخبز تحت ميعادى

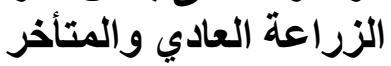

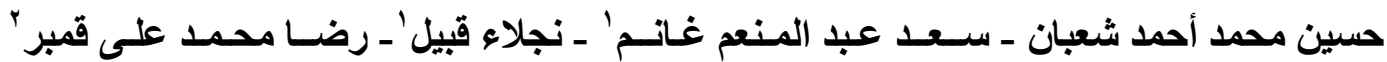

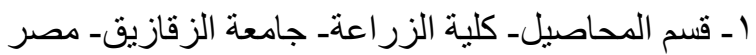 \\ r ـ قسم بحوث القمح- معهد بحوث المحاصيل الحقلية ـ مركز البحوث الزراعية ـ جيزة- مصر
}

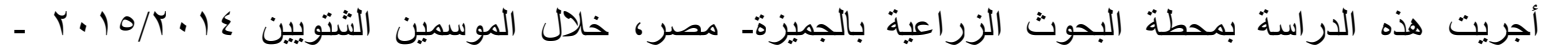

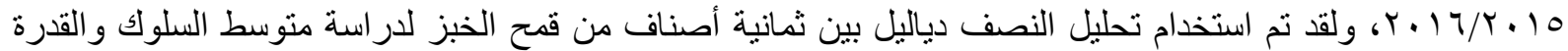

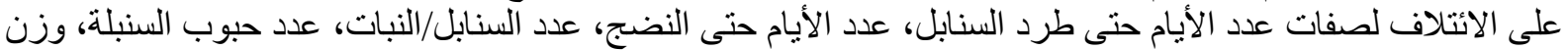

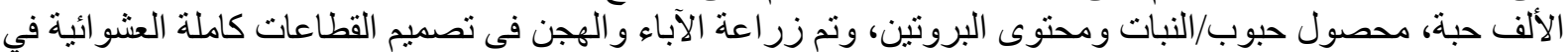

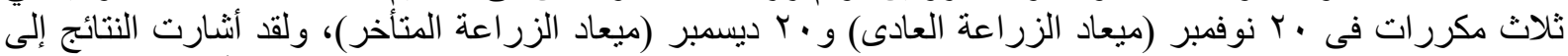

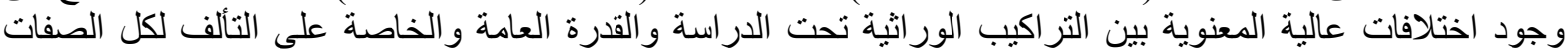

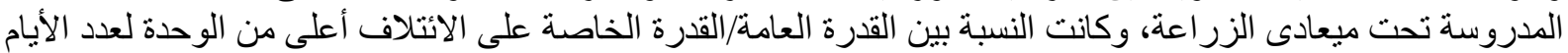

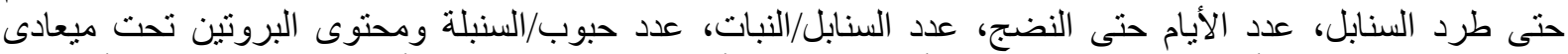

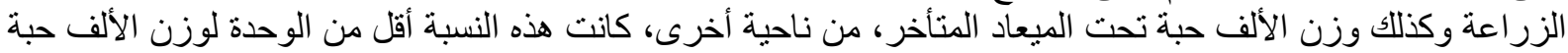

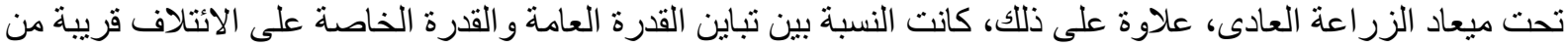

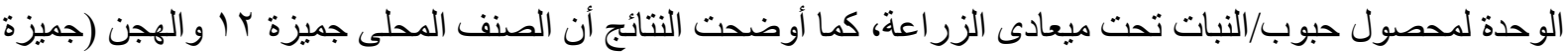

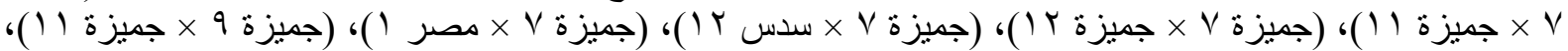

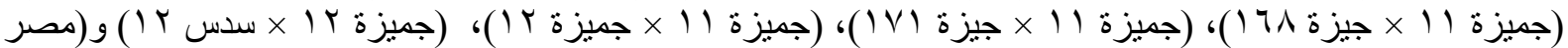

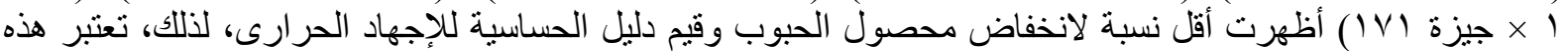

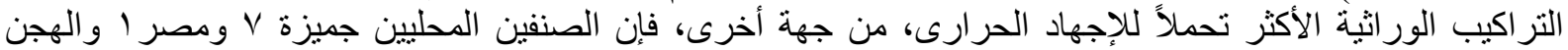

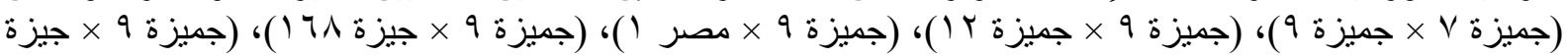

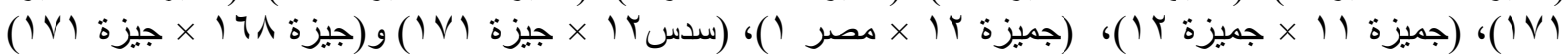

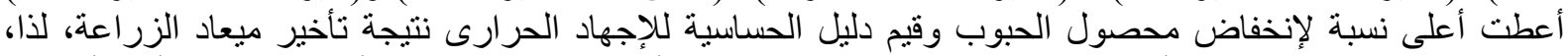

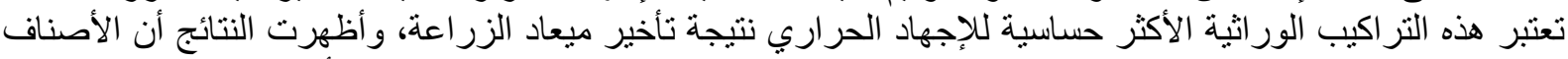

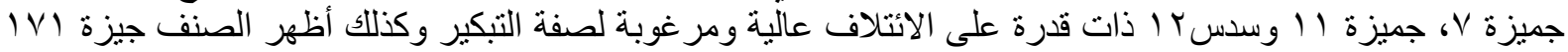

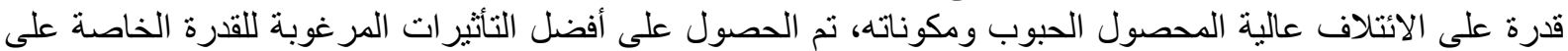

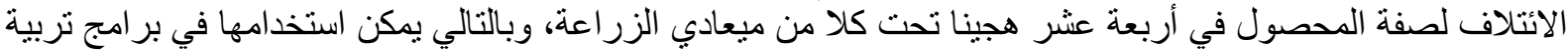
محصول القمح. 